\title{
A review of Gammiella Broth. in Africa, with a range extension to the East African islands and southern Africa
}

\author{
Brian J. O'Shea
}

141 Fawnbrake Avenue, London, SE24 OBG, UK

\begin{abstract}
Gammiella ceylonensis (Broth. in Herzog) W.R.Buck \& B.C.Tan is the only species of the genus in Africa. Clastobryella pusilla (Thér.) Wijk \& Margad., recorded from Madagascar, the only member of the genus still recorded on the moss checklist for Africa, is a synonym of Gammiella ceylonensis. Clastobryella foliicola P.de la Varde is not a synonym of Gammiella ceylonensis but probably an Ectropothecium, thus removing the only west African record for Gammiella. An extension of range into South Africa is also noted, so Gammiella is now known from east and southern Africa and Madagascar.
\end{abstract}

The genus Gammiella Broth. occurs only in the palaeotropics, and is widespread particularly in tropical Asia. Seven species are currently accepted in the genus, which has been revised and extended particularly by recent reviews of Sematophyllaceae subgen. Heterophyllioideae (and subgen. Clastobryoideae) (Tan \& Buck 1989; Tan 1990; Tan \& Jia 1999). Only one species has been found so far in Africa, Gammiella ceylonensis (Broth. in Herzog) B.C.Tan \& W.R.Buck, and this paper extends its distribution to Madagascar (by the acceptance of the synonymisation of Clastobryella pusilla (Thér.) Wijk \& Margad., thus losing the genus Clastobryella from the African list) and to KwaZulu-Natal, South Africa, by a recent collection by J.G. Duckett and H.W. Matcham.
It is also reported for the first time from Malawi and Uganda.

Clastobryella pusilla (Thér.) Wijk \& Margad. was first described by Thériot (1922) as Pterigynandrum madagassum based on a 1921 Perrier de la Bâthie collection from Madagascar, but as the specific epithet was already in use, the name was invalid and Thériot renamed it $P$. pusillum (Thériot 1926). Tixier (1977) mentioned two further Madagascar collections from 1924 (PC!) and 1931. Tixier (1977) included this taxon in the synonymy of Gammiella merrillii (Broth.) Tixier (now a synonym of $G$. ceylonensis), but as a number of the taxonomic descriptions and judgements in his paper have been shown to be suspect (see, 
for example, Tan \& Buck 1989; O'Shea 2000; O'Shea \& Buck 2001; this paper, Excluded taxon), and the paper contains a large number of mistakes in the quotations of type specimens and synonymy, this was not applied to the African checklist (O'Shea 1999) pending further analysis. Tan and Buck (1989) in their consideration of Philippine taxa reviewed Tixier's (1977) observations on Gammiella, and rejected many of the decisions he had made, and in turn proposed new synonymy, which is followed here. However, they did not consider non-Philippine taxa, such as Clastobryella pusilla.

The original description and illustration of Pterigynandrum madagassum (Thériot 1922) suggested strongly that the taxon is conspecific with Gammiella ceylonensis, and the type specimen leaves no doubt. As Tixier (1977) believed $G$. ceylonensis and $G$. merrillii were different taxa, this is the first time that Clastobryella pusilla has been synonymised with G. ceylonensis. All names used in relation to this taxon in Africa are included in the following summary:

Gammiella ceylonensis (Broth. in Herzog) B.C.Tan \& W.R.Buck, J. Hattori Bot. Lab. 66: 318. 1989; Clastobryum ceylonense Broth. in Herzog, Hedwigia 50: 137. 1911; Clastobryella ceylonensis (Broth.) Broth., Nat. Pfl. ed. 2, 11: 407. 1925.

Type: SRi LANKA. An einem Baum in Urwald des Pidurutalagala, ca. 2200 m., [1906, leg. Th. Herzog]. (isotype: BM!)

= Clastobryum merrillii Broth., Philipp. J.

Sci., C, 8: 81. 1913; Clastobryella merrillii (Broth.) M.Fleisch., Musci Fl. Buitenzorg 4: 1920. 1923; Gammiella merrillii (Broth.) Tixier, Rev. Bryol. Lichénol. 43: 440. 1977 (fide Tan \& Buck 1989: 318).

Type: PhILIPPINES. Luzon, Subprovince of Benguet, Pauai, on tree trunks, [May 1909,] [E.D.] Merrill 6677 (isotypes: $\mathrm{BM}$ !).

= Pterigynandrum pusillum Thér., Recueil

Publ. Soc. Havraise Etud. Div. 1925: 147.
1926; Clastobryella pusilla (Thér.) Wijk \& Margad., Taxon 8: 73. 1959; 三 Pterigynandrum madagassum Thér., Recueil Publ. Soc. Havraise Etud. Div. 89(2): 130. ic. 1922, hom. illeg.; Clastobryella madagassa (Thér.) Thér., Recueil Publ. Soc. Havraise Etud. Div. 1932: 144. 1932, nom. illeg. incl. spec. prior., syn. nov.

Type: Madagascar. Massif d'Andringitra, alt. between 1600-2500 m, leg. $M$. Perrier de la Bâthie, s.n. (holotype: PC!).

Illustrations: Thériot 1922: 130; Potier de la Varde 1932: 63; Tixier 1977: 441; Tan \& Buck 1989: 313. The last is the most helpful.

Distribution: In Asia, G. ceylonensis is known from India, Tibet, Sri Lanka, Indochina (Cambodia, Laos, Thailand, Vietnam), Malaya, Java, Bali, Philippines, Taiwan and China, whilst in Africa it is recorded from Tanzania, Uganda, Rwanda, Malawi, South Africa and Madagascar. (The record for Congo was based on Clastobryella foliicola, which is not regarded in this paper (see below) as belonging to Gammiella, and a record from Gabon was based on Potier de la Varde (1936), which merely repeated the details of the supposed Gammiella from neighbouring Congo, presumably as a taxon that might possibly occur in Gabon.) The known African distribution is shown in Fig. 1.

This distribution parallels that of several other mosses in the Sematophyllaceae, which are distributed most widely in Malesia/Indochina, and appear to have spread via Sri Lanka/India to the Indian Ocean islands, such as Clastobryophilum bogoricum and Acanthorrhynchium papillatum, and on to the Africa mainland, such as Radulina borbonica (O'Shea 2003).

Although the number of localities in Africa is quite low, Gammiella ceylonensis is a small and inconspicuous plant, often found amongst other (larger) plants and thus easily overlooked. It may well be more frequent than the map indicates: eleven collections were made on Mulanje Mountain, Malawi, where a special 


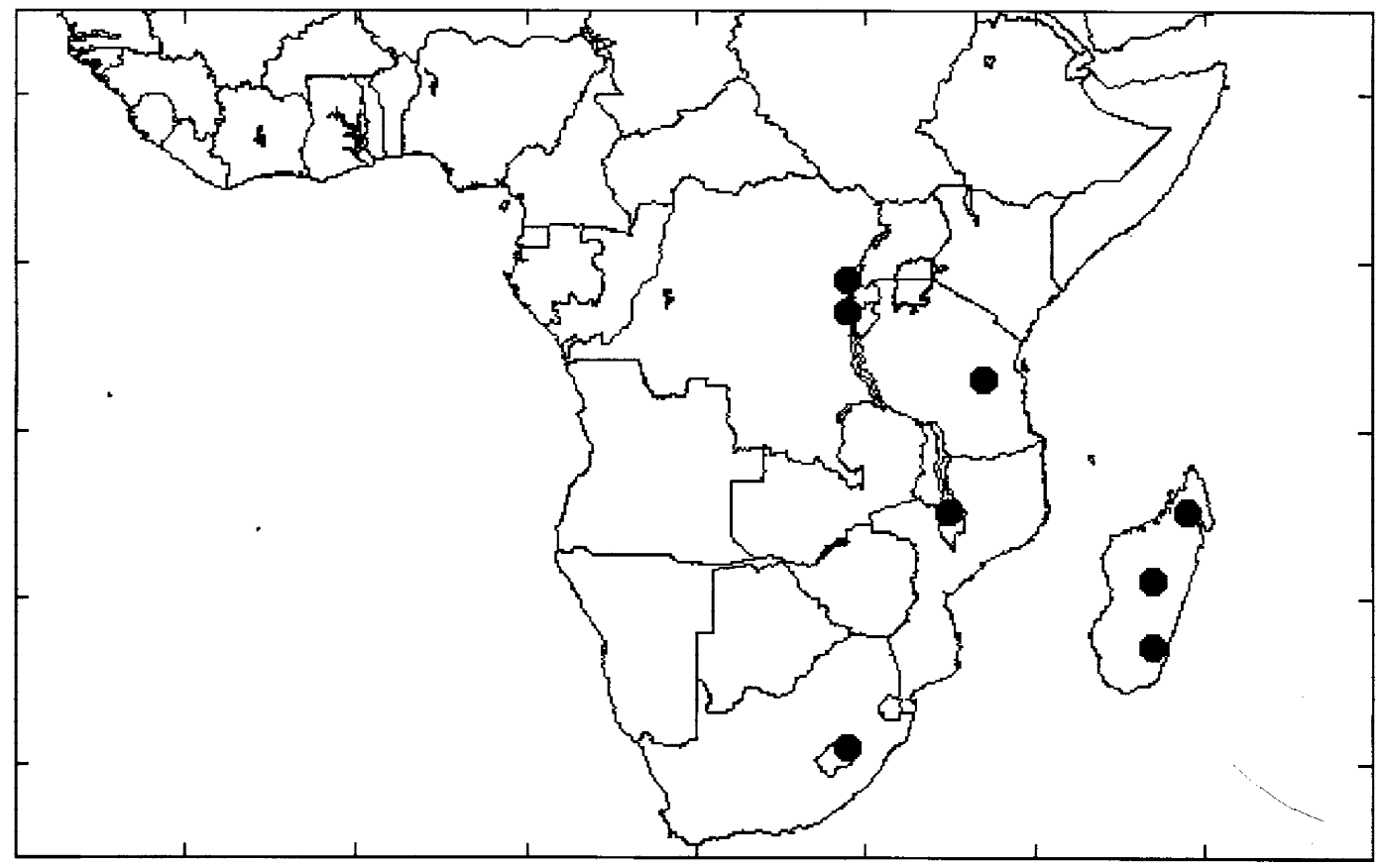

Figure 1. Distribution of Gammiella ceylonensis in Africa.

effort was made to separate out all taxa in mixed collections.

EXCLUDED TAXON: Clastobryella foliicola P.de la Varde, made a synonym of Gammiella merrillii by Tixier (1977) appears to belong elsewhere. The type specimen consists of five tiny plants embedded in mica, so it is difficult to be precise, but the plants are larger than Gammiella ceylonensis, have longer, very strongly prorate/ papillose cells and very few alar cells, and are likely to belong to Hypnaceae, possibly Ectropothecium.

Clastobryella foliicola P.de la Varde, Ann. Crypt. Exot. 5: 63. 2. 1932.

Holotype: Congo. Forêt de Libakala, Mosendjo, sur feuilles très coriaces, parmi les tiges rampantes et fortement appliquées d'un „Radula“, 5 August 1929 M. V. Babet No. 207 (= R. Potier de la Varde 4265)(PC!)

\section{SElected COLLeCtions EXAMined}

\section{AFRICA}

Madagascar. Massif d'Andringitra. leg. Perriere de la Bathie, 1921 (PC: Holo. of Pterigynandrum madagassum); Mt. Tsaratanana, 1600-2400 m, leg. Perrier de la Bathie, avril 1924. (PC)

Malawi. Mulanje: Mulanje Mt., Lichenya Plateau, small tributary of Lichenya R. on Fishing Path, branches of small tree overhanging shaded stream, S 1557' E 35³3', 1900 m, 25 June 1991, O’Shea 7449a (E, Hb. O'Shea) (see O'Shea \& Tan, in press)

South AfricA. KwaZulu-Natal: Champagne Castle (Central Drakenberg), north-facing basalt rock under Podocarpus sp. in fern forest, 1300 m, 24 April 1994, H.W. Matcham \& J.G. Duckett 1284a (PRE, Hb. Matcham, Hb. O'Shea).

UGANDA. Rukungiri: Bwindi-Impenetrable NP, Buhoma, Waterfall Trail, S $1^{\circ} 0^{\prime}$ E 213', 1585 
m, 7 February 1997, M.J. Wigginton $8345 e$, det. B.J. O'Shea (E)

\section{ASIA}

Philippines. Luzon, Benguet, Pauai, on tree trunks, May 1909, leg. E.D. Merrill 6677 (as Clastobryum merrillii - isotypes: BM Bм00667118, вм000667119).

SRI LANKA. Urwaldbaume des Pidurutalagala, ca. 2200 m., Jan 1906, leg. Th. Herzog. (as Clastobryum ceylonense - isotype: BM Bм000667120)

\section{REFERENCES}

O'Shea, B.J. 1999. Checklist of the mosses of subSaharan Africa (version 3, 11/99). Tropical Bryology Research Reports 1: 1-133.

O'Shea, B.J. 2000. Notes on Seychelles mosses. 6. A generic revision of Clastobryophilum M.Fleisch. (Sematophyllaceae, Bryopsida). Tropical Bryology 18: 97-105.

O'Shea, B.J. 2003. Bryogeographical relationships of the mosses of Sri Lanka. Journal of the Hattori Botanical Laboratory 93: 293-304.

O'Shea, B.J. \& Buck, W.R. 2001. Bryophytes of Uganda. 5. Bryocrumia L.E.Anderson (Hypnaceae, Musci), a monotypic genus new to Africa. Tropical Bryology 20: 103-107.
O'Shea, B.J. \& Tan, B.C. (in press). British Bryological Society Expedition to Mulanje Mountain, Malawi. 14. Sematophyllaceae (Bryopsida)

Potier de la Varde, R. 1932. Récoltes bryologiques en Afrique Équatoriale Française. Annales de Cryptogamie Exotique 5: 53-67

Potier de la Varde, R. 1936. Mousses du Gabon. Sant-Lo: R. Jacqeline.

Tan, B.C. 1990. Six new taxa of Malesian mosses. Bryologist 93: 429-437.

Tan, B.C. \& Buck, W.R. 1989. A synoptic review of Philippine Sematophyllaceae with emphasis on Clastobryoideae and Heterophylloideae (Musci). Journal of the Hattori Botanical Laboratory 66: 307-320.

Tan, B.C. \& Jia, Y. 1999. A preliminary revision of Chinese Sematophyllaceae. Journal of the Hattori Botanical Laboratory 86: 1-70.

Thériot, I. 1922. Deuxième contribution à la flore bryologique de Madagascar. Recueil des Publications de la Société Havraise d'Études Diverses 1922: 111-132.

Thériot, I. 1926. Cinquième contribution à la flore bryologique de Madagascar. Recueil des Publications de la Société Havraise d'Études Diverses 1925: 122-151.

Thériot, I. 1932. Huitième contribution à la flore bryologique de Madagascar. Recueil des Publications de la Société Havraise d'Études Diverses 1932: 132-154.

Tixier, P. 1977. Clastobryoidées et taxa apparentés. Revue Bryologique et Lichenoloique 43: 397-464. 